\title{
ACTH CONTENT IN THE NEUROHYPOPHYSIS OF RAT
}

\author{
Shinji ITOH* \\ Department of Physiology, Hokkcido University, School of Medicine, Sapporo
}

Role of the neurohypophysis in the release of $\mathrm{ACTH}$ has been studied by a number of investigators. Posterior pituitary hormone; particularly vasopressin, was proposed as a neurohormone which stimulates the secretion of ACTH from the anterior lobe ${ }^{1-4}$. A group of workers ${ }^{5-7}$, however, have shown that commercial posterior pituitary hormone preparations are contaminated with corticotrophin-releasing factor, CRF. It was also reported that the neurohypophysis contains considerable amount of ACTH. According to MralHE-Voloss ${ }^{8)}$ and Rochefort et al. ${ }^{9)}$, ACTH content of the anterior lobe is diminished by systemic stimuli, while a fall in ACTH of the posterior lobe is caused by neurogenic stimuli. The present experiments were carried out to confirm the occurrence of ACTH activity in the neurohypophysis of rat.

\section{METHODS}

Male Holtzman rats, weighing 170 to $220 \mathrm{~g}$, were used throughout the experiments. Rats were quickly killed by mannual separation of the cervical vertebrae or decapitation. Anterior and posterior lobes of pituitary gland were dissected out employing a dissecting microscope. Three to six glands were pooled and extracted with $0.1 \mathrm{~N}$ $\mathrm{HCl}$. The extracts were neutralized and diluted with Krebs-Ringer bicarbonate solution at $\mathrm{pH} 7.4$.

These samples were assayed for corticosterone-releasing capacity in vitro ${ }^{10}$ and for adrenal ascorbic acid depleting activity in hypophysectomized ratsi1). For the in vitro assay, eight rats were sacrificed for one assay. The adrenals obtained from these rats were freed from adhering tissue, and the glands quartered. The eight quarters obtained from two glands of each rat were incubated in $1.5 \mathrm{ml}$ Krebs-Ringer bicarbonate buffer ( $\mathrm{pH} 7.4$ ) at $37.5^{\circ} \mathrm{C}$, for 1 hour under oxygen containing 5 per cent carbon dioxide in a Dubnoff incubator. Glucose was added into the above medium in a concentration of $200 \mathrm{mg}$ per cent. After 1 hour preincubation, the medium was poured off and discarded. An equal quantity of fresh medium was added with $0.1 \mathrm{ml}$ of test sample. After 2 hour incubation corticosterone discharged by the adrenal tissue into the medium was determined by fluorometric method ${ }^{12}$. For the ACTH assay by adrenal ascorbic acid depletion method, hypophysectomy was performed through the external auditory canal. Ascorbic acid concentration was determined by the method of ROE and KUETHER ${ }^{13)}$. The activity was expressed in term of milli-units of standard ACTH. ACTH preparation used in this experiment as standard was provided by Armour Co. (Lot \#216-172-5).

\footnotetext{
Received for publication December 29, 1961.

* 伊藤真次
} 


\section{RESULTS AND DISCUSSION}

1. Release of corticosterone in vitro. FIG. 1 shows dose-response curve; ordinate indicates the amount of corticosterone released by $100 \mathrm{mg}$ adrenal tissue during 2 hour incubation in Krebs-Ringer bicarbonate solution with glucose, and abscissa represents the amount of ACTH added into the incubation medium.

ACTH activity of the anterior lobe was $1242 \pm 101 \mathrm{mU}$ per gland and $283 \pm 21.0 \mathrm{mU}$ per $\mathrm{mg}$ fresh tissue. The activity of the posterior lobe was $53 \pm 4.8 \mathrm{mU}$ per gland and $88 \pm 7.6 \mathrm{mU}$ per $\mathrm{mg}$. The $\mathrm{ACTH}$ content per mg posterior lobe tissue was approximately onethird as much as that of the anterior lobe tissue. This value of the anterior lobe ACTH was almost the same as the values reported by Birmingham et al. ${ }^{14)}$ and RoberTs ${ }^{15)}$,

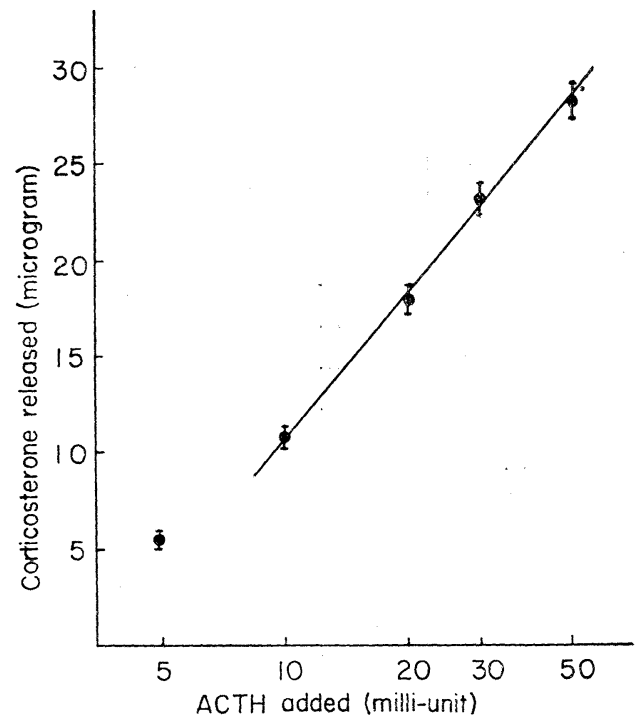

FIG. 1. Dose-response curve. but considerably higher than those by ForTIER ${ }^{16,17)}$ and KitAy et al. ${ }^{18)}$. According to ROCHEFORT et al. ${ }^{9}$, ACTH content of the anterior lobe was roughly $150 \mathrm{mU}$ per $\mathrm{mg}$ and that of the posterior lobe about $35 \mathrm{mU}$. ROBERTS ${ }^{15}$ ) claimed that the release of corticosterone by rat adrenal tissue in vitro was markedly responsive to rat $\mathrm{ACTH}$ and much less responsive to $\mathrm{ACTH}$ from other sources. This might be the case. However, no explanation can be afforded for such large differences in those values obtained by different investigators.

To know the direct effect of vasopressin on the adrenal gland, HiLToN et $a .^{19,20)}$ performed an arterial perfusion experiment in dogs, and found that vasopressin stimulated the secretion of hydrocortisone. High value might be obtained by the posterior pituitary hormone which is possibly contained in the

TABLE 1.

ACTH content of rat pituitary gland.

\begin{tabular}{l|c|c|c|c} 
& No. of expts. & $\begin{array}{c}\text { Average tissue } \\
\text { weight } \\
(\mathrm{mg})\end{array}$ & \multicolumn{2}{|c}{ ACTH content (mU) } \\
\cline { 2 - 4 } & 14 & 4.44 & per gland & per mg \\
\hline Anterior lobe & 15 & 0.61 & $1242 \pm 101$ & $283 \pm 21.0$ \\
Posterior lobe & $53 \pm 4.8$ & $88 \pm 7.6$ \\
\hline
\end{tabular}


extracts. Therefore, the direct effect of vasopressin on rat adrenal tissue was tested in vitro, by adding 20 to $200 \mathrm{mU}$ Pitressin (Parke-Davis Co.) in each incubating flask. As shown in TABLE 2, we failed to flnd any stimulatory effect of this hormone on the release of corticosterone.

TABLE 2.

Effect of Pitressin on the release of corticosterone by rat adrenal tissue in vitro.

\begin{tabular}{c|c|c|c|c|c}
\hline $\begin{array}{c}\text { Pitressin } \\
\text { added } \\
(\mathrm{mU})\end{array}$ & $\begin{array}{c}\text { ACTH added } \\
(\mathrm{mU})\end{array}$ & $\begin{array}{c}\text { No. of } \\
\text { expts. }\end{array}$ & \multicolumn{3}{|c|}{ Corticosterone released* } \\
\cline { 3 - 5 } & - & 5 & with & without & diff. \\
\hline 20 & - & 5 & 13.2 & 13.0 & +0.2 \\
50 & - & 5 & 13.1 & 13.0 & -0.5 \\
100 & - & 5 & 12.7 & 13.7 & -0.6 \\
200 & 10 & 9 & 22.8 & 13.1 & -0.4 \\
\hline- & 10 & 7 & 19.9 & 10.4 & +10.5 \\
20 & 10 & 8 & 21.1 & 10.9 & +9.5 \\
50 & 10 & 7 & 20.8 & 10.4 & +10.2 \\
100 & & 5 & & \\
\hline
\end{tabular}

* microgram per $100 \mathrm{mg}$ adrenal tissue.

According to ROYCE and SAYERS ${ }^{21}$, Pitressin potentiates the action of ACTH in hypophysectomized rats. In the present experiment 20 to $100 \mathrm{mU}$ Pitressin was added with $10 \mathrm{mU}$ ACTH into the flask. The amount of corticosterone released was the same in every case, either absence or presence of Pitressin. From these results it would be inferred that inclusion of vasopressin in the pituitary extracts does not impede the assay of ACTH in vitro.

Effect of brain extracts on the release of corticosterone was also observed as control experiment. For the assay of ACTH content the amount of anterior lobe tissue added into each flask was approximately $0.1 \mathrm{mg}$ and that of posterior lobe tissue 0.1 to $0.2 \mathrm{mg}$. In this control experiment the tuber cinereum and brain cortex tissues in a quantity of $1 \mathrm{mg}$ or more were added in the flask. It

TABLE 3.

Effect of brain tissue on the release of corticosterone by rat adrenal tissue in vitro.

\begin{tabular}{|c|c|c|c|c|c|}
\hline & \multirow{2}{*}{$\begin{array}{l}\text { No. of } \\
\text { expts. }\end{array}$} & \multirow{2}{*}{$\begin{array}{c}\text { Average } \\
\text { weight of } \\
\text { tissue } \\
\text { added (mg) }\end{array}$} & \multicolumn{3}{|c|}{ Corticosterone released* } \\
\hline & & & $\begin{array}{c}\text { with } \\
\text { extract }\end{array}$ & $\begin{array}{l}\text { without } \\
\text { extract }\end{array}$ & diff. \\
\hline Tuber cinereum & 10 & 1. 25 & 12.7 & 12.6 & +0.1 \\
\hline Brain cortex & 4 & 1.55 & 14.4 & 14.8 & -0.4 \\
\hline
\end{tabular}

* microgram per $100 \mathrm{mg}$ adrenal tissue. 
is well known that hypothalamic tissue contains various kinds of substances such as histamine, serotonin, norepinephrin, substance $P$, and so on. However, as shown in TABLE 3 , these extracts had no activity in releasing corticosterone in vitro.

2. Adrenal ascorbic acid depletion in hypophysectomized rats. ACTH activity of the pituitary extracts was reexamined by the method of SAYERS et al. ${ }^{11}$. As shown in FIG. 2, intravenous administrations of standard ACTH in doses from $0.5 \mathrm{mU}$ to $2.0 \mathrm{mU}$ per $100 \mathrm{~g}$ body weight into previously hypophysetomized rats caused a marked depletion in adrenal ascorbic acid content, while both anterior and posterior lobe extracts had no effect at all, if dose of the extracts was less than $2 \mathrm{mU}$ equivalent $\mathrm{ACTH}$ activity as determined by the in vitro method.

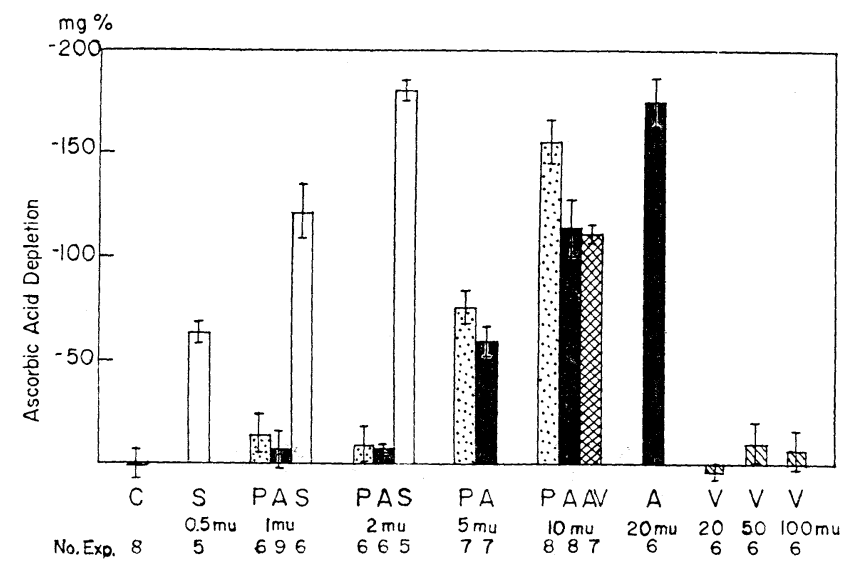

FIG. 2. Adrenal ascorbic acid depletion due to standard ACTH (S), anterior lobe extract $(\mathrm{A})$, posterior lobe extract $(\mathrm{P})$, and vasopressin $(\mathrm{V})$. C: control, $0.85 \% \mathrm{NaCl}$.

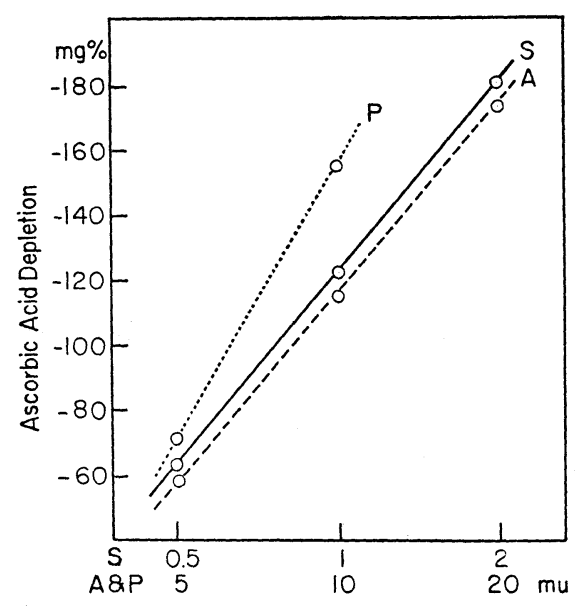

FIG. 3. Dose-response curve. $\mathrm{S}$ : standard ACTH, A: anterior lobe extract, $\mathrm{P}$ : posterior lobe extract. 
When the extracts were injected more than $5 \mathrm{mU}$ (determined by the in vitro method), adrenal ascorbic acid concentration decreased markedly to similar extent as observed after one-tenth dose of standard ACTH. FIG. 3 shows log dose-response curves of these three samples. Slope of the curve of the anterior lobe extract was almost the same as that of the standard preparation, but the curve of the posterior lobe extract was steeper than the curves of the formers. From this figure it will be found that $1 \mathrm{mU}$ standard ACTH activity is equivalent to $10.9 \mathrm{mU}$ anterior lobe extract and $7.6 \mathrm{mU}$ posterior lobe extract as determined by the in vitro method. If calculation was done from these values, ACTH content of the anterior lobe will be $114 \mathrm{mU}$ per gland and $25.9 \mathrm{mU}$ per $\mathrm{mg}$, and that of the posterior lobe $7.0 \mathrm{mU}$ per gland and $11.6 \mathrm{mU}$ per $\mathrm{mg}$.

It seems probable that the neurohypophysial factor, compared with the adenohypophysial ACTH, is more active to deplete adrenal ascorbic acid content than to cause the release of corticosterone. Contamination with vasopressin of the posterior lobe extract may cause such discrepancy. However, it was found that vasopressin in doses ranging $20 \mathrm{mU}$ to $100 \mathrm{mU}$ had no effect on the adrenal ascorbic acid content, nor $100 \mathrm{mU}$ of Pitressin did cause any potentiation of the activity of anterior lobe extract. Posterior lobe extract may contain material(s) other than vasopressin, which potentiate(s) ACTH activity in depleting adrenal ascorbic acid concentration, or ACTH in the posterior lobe may be different in nature from that in the anterior lobe.

Employing neurohypophysectomized rats, ARIMURA and $\mathrm{LONG}^{22}$ found that there was no increase in blood ACTH level after painful stimuli, nor decrease in adrenal ascorbic acid concentration after epinephrine in such animals. Similar results were obtained by SMELIK ${ }^{23)}$. According to him, the effect of psychic stress was completely abolished in neurohypophysectomized rats, whereas a somatic stress induced a normal ascorbic acid depletion. Since the effect of epinephrine was also entirely inhibited in neurohypophysectomized rats, he proposed a hypothesis that neurogenic stimuli act in the ACTH in the posterior lobe by the mediation of endogenous adrenaline, whereas in the case of somatic stress neither the posterior lobe nor adrenaline is involved. Observing plasma corticosterone levels, DE $\mathrm{WIED}^{24)}$ studied the adrenocortical response to stresses in neurohypophysectomized rats, and found that the response to neurogenic stimuli was partially, but not entirely, blocked, and that exposure to systemic stress elicited an increase in the corticosterone levels similar to that found in controls. Results obtained by other investigators were not in agree with the above observations. NowELL ${ }^{25}$ ) reported that in neurohypophysectomized rats adrenocortical response to cold exposure and injection of hypertonic saline was completely inhibited, whereas the response to exposure to a ringing bell was not inhibited. This result is reverse to that obtained by ARIMURA and SMelik. Recent studies of Mialhe-Voloss ${ }^{8)}$ and ROCHEForT et al. ${ }^{9}$ have shown that neurogenic stimuli cause an ACTH release from the posterior lobe, 
whereas somatic stimuli induce an ACTH depletion from the anterior lobe. Thus, physiological significance of neurohypophysial ACTH is now becoming apparent.

FISHER and DE SALVA ${ }^{26)}$ claimed that neurohypophysectomy did not inhibit an increase in plasma corticosterone, but did block adrenal ascorbic acid depletion response following epinephrine. According to SLUSHER ${ }^{27)}$, lesions in the posterior and mid-central portions of the hypothalamus specifically inhibited corticosterone discharge without altering adrenal ascorbic acid response and lesions in the basal tuberal region inhibited adrenal ascorbic acid depletion without affecting corticosterone response in response to somatic stress. These observations could be explained by the existence of two separate adrenocorticotropic factors. To solve the problem, however, further experiments in which ACTH is isolated from the neurohypophysis should be carried out.

\section{SUMMARY}

1. ACTH activity of anterior and posterior lobe extracts obtained from adult male rats was determined by the in vitro method of SAFFRAN and SCHALLY and by the method of SAYERS et al.

2. In case $\mathrm{ACTH}$ activity was measured by the in vitro method, the activity of the anterior lobe was $1242 \pm 101 \mathrm{mU}$ per gland and $283 \pm 21.0 \mathrm{mU}$ per $\mathrm{mg}$ fresh tissue, and that of the posterior lobe $53 \pm 4.8 \mathrm{mU}$ per gland and $88 \pm 7.6 \mathrm{mU}$ per $\mathrm{mg}$.

3. Markedly less activity was obtained by the method of SAYERS : $1 \mathrm{mU}$ standard ACTH activity was equivalent to $10.7 \mathrm{mU}$ anterior lobe extract and 7.6 $\mathrm{mU}$ posterior lobe extract as determined by the in vitro method.

4. Pitressin in doses used in the present experiments had no effect on rat adrenal tissue in vitro in releasing corticosterone, nor potentiating the activity of ACTH added together. Pitressin did not cause any depletion in adrenal ascorbic acid concentration in hypophysectomized rats, nor potentiate ACTH activity of the anterior lobe extract.

5. Brain extracts did not show any ACTH activity in vitro.

The author wishes to express sincere gratitude to Dr. AlBert B. Eisenstern of the Jewish Hospital of St. Louis for his generous help in this work performed in his laboratory.

\section{REFERENCES}

1) McCAnn, S. M. And BRobeck, J.R. Evidence for a role of the supraoptico-hypophyseal system in regulation of adrenocorticotrophin secretion. Proc. Soc. Exper. Biol. and Med. 87 : 318, 1954.

2) McCANn, S.M. The ACTH-releasing activity of extracts of the posterior lobe of the pituitary in vivo. Endocrinology 60:664, 1957. 
3) Stein, M. And Mirsky, I. A. The relation between anterior and posterior hypophysis and the hypothalamus in response to stress. 'Hypothalamic-hypophysial interrelationships' ed. by Fields, W.S., Guillemin, R. and Carton, C. A., Thomas, Springfield, 1956, p. 58.

4) Casentini, S., De Poli, A., Hukovic, S. and Martini,. L. Studies on the control of corticotrophin release. Endocrinology. 64: 403, 1959.

5) Guillemin, R. and Hearn, W. R. ACTH release by in vitro pituitary. Effect of pitressin and purified argininevasopressin. Proc. Soc. Exper. Biol. and Med. 89: 365, 1955.

6) Guillemin, R., Hearn, W. R., Cheek, W.R. and Housholder, D. E. Control of corticotrophin release: further studies with in in vitro methods. Endocrinology. 60: 488, 1957.

7) Schally, A. V., Saffran, M. ANd Zimmermann, B. A corticotrophin-releasing factor: partial purification and amino acid composition. Biochem. J. 70: 97, 1958.

8) Mialhe-Voloss, C. Posthypophyse et activité corticotrope. Acta Endocr. Suppl. 35, 1958.

9) Rochefort, G. J., Rosenberger, J. and Saffran, M. Depletion of pituitary corticotrophin by various stresses and by neurohypophyseal preparations. J. Physiol. 146: 105, 1959.

10) Saffran, M. And Schally, A. V. In vitro bioassay of corticotrophin: modification and statistical treatment. Endocrinology. $56: 523,1955$.

11) Sayers, M. A., Sayers, G. And Woodbury, L. A. The assay of adrenocorticotrophic hormone by the adrenal ascorbic acid depletion method. Endocrinology 42:379, 1948.

12) Silber, R. H., Busch, R. D. and Oslapas, R. Practical procedure for estimation of corticosterone and hydrocortisone. Clin. Chem. $4: 278,1958$.

13) Roe, J. H. And Kuether, C. A. The determination of ascorbic acid in whole blood and urine through the 2,4- dinitrophenylhydrazine derivative of dehydroascorbic acid. J. Biol. Chem. 147: 399, 1943.

14) Birmingham, M. K., Kurlents, E., Rochefort, G. J., Saffran, M. and Schally, A. V. ACTH content of rat pituitary glands. Endocrinology. 59:677, 1956.

15) Roberts, S. Corticosteroid-releasing activity in blood. Ciba Found. Colloq. Endocrinol. $11:$ 167, 1957.

16) Fortier, C. Pituitary ACTH and plasma free corticosteroids following bilateral adrenalectomy in the rat. Proc. Soc. Exper. Biol. and Med. 100:13, 1959.

17) ForTier, C. Effect of hydrocortisone on pituitary ACTH and adrenal weight in the rat. Proc. Soc. Exper. Biol. and Med. 100: 16, 1959.

18) Kitay, J. I., Holud, D. A. And Jailer, J.W. Hormonal regulation of pituitary adrenocorticotrophin. Proc. Soc. Exper. Biol. and Med. 97 : 165, 1958.

19) Hilton, J. G., Scian, L.F., Westermann, C. D. and Kruesi, O. R. Direct stimulation of adrenocortical secretion by synthetic vasopressin in dogs. Proc. Soc. Exper. Biol. and Med. 100: 523, 1959.

20) Hilton, J. G., Scian, L.F., Westermann, C. D., Nakano, J. and Kruesi, O.R. Vasopressin stimulation of the isolated adrenal glands: nature and mechanism of hydrocortisone secretion. Endocrinology 67:298, 1960.

21) Royce, P.C. and Sayers, G. Extrapituitary interaction between pitressin and ACTH. Proc. Soc. Exper. Biol. and Med. $98:$ 70, 1958.

22) Arimura, A. And Long, C. N. H. (unpublished)

23) Smelik, P. G. Mechanism of hypophysial response to psychic stress. Acta Endocr. $33: 437,1960$.

24) DE WIED, D. The significance of the antidiuretic hormone in the release mechanism 
of corticotropin. Endocrinology 68: 956, 1961.

25) Nowell, N.W. Studies in the activation and inhibition of adrenocorticotrophin secretion. Endocrinology $64: 191,1959$.

26) Fisher, J. D. And De Salva, S. J. Plasma corticosterone and adrenal ascorbic acid levels in adeno- and neurohypophysectomized rats given epinephrine postoperative1y. Amer. J. Physiol. $197:$ 1263, 1959.

27) Slusher, M. A. Dissociation of adrenal ascorbic acid and corticosterone response to stress in rats with hypothalamic lesions. Endocrinology 63: 412, 1958. 